\title{
Management of cataract
}

Rumona Dickson, Alison Eastwood, Paramjit Gill, Arabella Melville, Susan O'Meara,
Trevor Sheldon

This review is based on Effective Health Care, Volume 2, Bulletin No 3

\section{NHS Centre for Reviews and Dissemination, University of York Rumona Dickson, research fellow Alison Eastwood, research fellow Arabella Melville, research fellow Susan O'Meara, research fellow \\ Trevor Sheldon, director}

Centre for Research in Primary Care University of Leeds Paramjit Gill, research tutor

Correspondence to: Dr Rumona Dickson, NHS Centre for Reviews and Dissemination, University of Dissemination, Univers
York, York YO1 5DD
Cataract is an opacity in the lens which can block or scatter light. Vision may become blurred or cloudy, colours may be seen differently, and people may experience problems with glare from the sun or from lamps - for example, during night driving. Most people with cataract, if left untreated, will eventually become severely visually disabled.

The focus of this review is age related (or senile) cataract, defined as lens opacity in people over 50 when causes other than age (genetic, congenital, metabolic, traumatic, or toxic) have been excluded. ${ }^{1}$ This constitutes most cataracts. The aim is to summarise research results relevant to some of the key issues in the provision of high quality, cost effective health care for people with cataract.

\section{Assessment}

Cataract assessment includes verifying the presence of a cataract and assessment of the degree to which visual impairment and disability is caused by cataract. Simple physical examination of the eye is the most common method used to identify cataract. Visual acuity, glare disability, and contrast sensitivity are three dimensions of visual function affected, although none is specific to cataract. ${ }^{23}$

The Snellen visual acuity test is most commonly used for the assessment of cataract and as an outcome measure for treatment, but it is not sensitive to problems of glare or reduced contrast sensitivity, ${ }^{45}$ which may prove to be disabling even when visual acuity is near normal. ${ }^{67}$

A study of older people in inner city London ${ }^{8}$ indicated that a large proportion with considerable visual impairment due to cataract had not been identified by the health service. Similar findings were reported from other United Kingdom community based studies. ${ }^{910}$

Various tests are available to assess glare disability ${ }^{112}$ and contrast sensitivity. ${ }^{13-19}$ These may be of some use when assessing patients reporting reduced visual functioning but with no significant impairment of acuity.

There is a poor correlation between visual acuity and visual function. ${ }^{40}$ To assess need it may be necessary to move towards measures of visual functioning which take account of the effects on social functioning and quality of life..$^{4-21}$ Several questionnaires that measure functioning have recently been developed. ${ }^{20} 2223$ Unfortunately, clinical decisions are often based on tests of visual acuity, and the degree to which everyday functioning is affected is rarely noted. ${ }^{24}$

Impairment of vision with symptoms similar to those associated with cataract can be due to other coexisting eye problems and it is important to assess comorbidity which might reduce the degree of improvement after cataract extraction. ${ }^{2526}$ This can be done with the patient's history and thorough ocular examination. Early detection and referral to an ophthalmologist may facilitate the assessment of retinal disease before the fundus becomes difficult to see through an advancing cataract.

Several tests of potential vision (such as electrophysiological tests) are available to try to predict visual function after surgery. A systematic review published in 1993 concluded that there was no evidence that these tests contribute more information than that which could be derived from comprehensive history and ocular examination. ${ }^{27}$

\section{Treatment}

Very few randomised controlled trials have been carried out to evaluate the effectiveness of treatments for cataract. Most of the research in this area is based on case series which, because they do not use comparable control groups, may provide biased estimates of the impact of different treatment methods. ${ }^{28}$ Shifts in care such as changes from intracapsular to extracapsular surgery have been made on the basis of professional judgement and personal choice, not reliable evidence of effectiveness and cost effectiveness.

\section{Prevention and medical treatments}

The cause of cataract is not known and there is no evidence related to risk factors for cataract. No medical treatments have been shown to be effective in prevention or treatment of cataract. ${ }^{2930}$ There have been several epidemiological studies exploring the potential protective effects of nutrients, but the results are inconclusive. ${ }^{31-35}$ 


\section{Surgical treatment}

Extraction of cataract is one of the most common elective surgical procedures. Surgical treatment involves removing the lens and replacing it with an artificial lens. Over the past 15 years there have been major changes in surgical technique.

Ninety five per cent of operations in the United Kingdom use extracapsular cataract extraction (ECCE), which involves removal of the lens (nucleus and cortical material), leaving behind the posterior capsule..$^{25-36}$ Intracapsular surgery, in which the entire lens is removed including the capsule, is no longer thought to have a role in routine surgery. ${ }^{37}$

In standard extracapsular surgery, the lens nucleus is removed intact and the remaining cortical material is aspirated. Increasingly, however, phacoemulsification is used to break up the nucleus with ultrasound so that it can be removed through a thin cannula. This requires a smaller incision and fewer, if any, sutures. Phacoemulsification predominates in North America and a shift to its use is taking place in the United Kingdom. ${ }^{25}$

Phacoemulsification is generally thought to be more effective than standard extracapsular surgery, but no completed randomised controlled trials directly comparing visual and health outcomes, complications, or costs of these techniques were identified. ${ }^{38}{ }^{39} \mathrm{~A}$ Medical Research Council (MRC) randomised controlled trial currently in progress at Moorfields and Oxford Eye Hospitals will provide comparative information on outcomes and costs.

\section{Surgical outcomes}

No randomised controlled trials comparing cataract surgery with no treatment or placebo have been identified. However, progression studies show that cataracts do not show much spontaneous improvement. ${ }^{40-42}$ Case series show dramatic improvements in visual outcomes of people who undergo cataract surgery and therefore offer reliable evidence of its effectiveness.

A systematic review of cohort studies and case series published in English between 1975 and 1991 which looked at outcomes of cataract surgery was the basis for the United States Agency for Health Care Policy and Research clinical practice guidelines (appendix). ${ }^{2838}$ This review considered 57 studies which reported changes in visual outcome in 17390 eyes after cataract surgery.

Table 1 Proportion of eyes experiencing complications after cataract surgery and intraocular lens implantation (adapted from Powe et al, 1994 $4^{38}$ )

\begin{tabular}{|c|c|c|c|}
\hline Complication & $\begin{array}{l}\text { Studies } \\
n\end{array}$ & $\begin{array}{l}\text { Total eyes } \\
n\end{array}$ & $\begin{array}{l}\text { Pooled complication rate } \\
\% \text { eyes }(95 \% \text { CI) }\end{array}$ \\
\hline \multicolumn{4}{|l|}{ Major, early: } \\
\hline Endophthalmitis & 16 & 30656 & $0.13(0.09-0.17)$ \\
\hline \multicolumn{4}{|l|}{ Major, late: } \\
\hline Bullous keratopathy & 27 & 15951 & $0.3(0.2-0.4)$ \\
\hline $\begin{array}{l}\text { Malposition or dislocation of intraocular } \\
\text { lens }\end{array}$ & 40 & 17944 & $1.1(0.9-1.2)$ \\
\hline Clinical cystoid macular oedema & 43 & 20671 & $1.4(1.2-1.6)$ \\
\hline Angiographic cystoid macular oedema & 9 & 4236 & $3.5(2.9-4.0)$ \\
\hline Retinal detachment & 42 & 33603 & $0.7(0.6-0.8)$ \\
\hline \multicolumn{4}{|l|}{ Other, late: } \\
\hline Posterior capsule opacification & 41 & 14677 & $19.7(19.1-20.3)$ \\
\hline
\end{tabular}

These studies were pooled (weighting for sample size) to give overall estimates for the proportion of patients who achieved visual acuity of $20 / 40(6 / 12)$ or better. Of eyes with no coexisting eye disease - for example, age related macular degeneration or glaucoma $95.5 \%$ (95\% confidence interval (95\% CI) $95.1 \%$ to $95.9 \%$ ) reached this level of visual acuity, as did $89.7 \%$ (95\% CI $89.3 \%$ to $90.2 \%$ ) of all eyes.

Similar visual acuity results were presented in the report of the national cataract surgery survey in the United Kingdom ${ }^{26}$ which reported that $80 \%$ of patients $(90 \%$ of those with no coexisting eye disease) reached at least $6 / 12(20 / 40)$ acuity. Studies measuring visual functioning have also shown that high proportions of patients report benefits. ${ }^{20-45}$

These studies showed that coexisting eye disease is not necessarily a contraindication for cataract surgery. However, because it influences the outcome, it is important to assess eye disease and discuss it with patients so that they have more realistic expectations of the likely improvement after surgery.

\section{Complications}

Although highly effective, cataract surgery does result in some complications. ${ }^{384647}$ The only systematic review of this area is by Powe et al (appendix).$^{38}$ Eighty three cohort or case studies reporting complications were considered, including 68316 eyes receiving cataract surgery. Table 1 shows the pooled complication rates (weighted for sample size and where appropriate by quality score). An examination of Medline from 1991 to 1995 by the Effective Health Care Team showed that more recent studies gave results consistent with the findings of this review.

The most common complication of cataract surgery is opacification of the posterior capsule, the part of the lens left behind after extracapsular extraction. Reported incidences increase in proportion to the duration of follow up, with $15 \%-20 \%$ of eyes affected after two years. ${ }^{27}$ A review of United States Medicare beneficiaries showed that $24 \%$ of $57 \quad 100$ patients were treated for opacification within three years of cataract surgery. ${ }^{48}$ This has implications for the cost of services and the way treatments are purchased.

Opacification of the posterior capsule can be quickly treated in an outpatient department with Nd Yag (neodymium: yttriumaluminium-garnet) laser. The study of Medicare data reported that laser treatment is associated with a nearly fourfold increase in the risk of a break or detachment of the retina. ${ }^{48}$ Although the overall risk of a retinal detachment with laser treatment is low (0 to $4 \%)^{27}$ and can be effectively treated, it should be discussed with patients considering cataract surgery. It may be that the laser technique and lower laser energy intensity used in the United Kingdom produce a lower rate of retinal detachment. This remains an issue for research. 


\section{Second eye surgery}

Most people with cataract in one eye have, or will develop cataract in their second eye. ${ }^{49}$ This raises two questions: whether patients benefit from removal of the second cataract, and if so whether both should be removed in a single operative session.

The few relevant studies in this area strongly suggest that patients with cataract in both eyes (bilateral cataract) derive considerable extra benefit by having both cataracts removed. A recent study compared the outcomes in 426 patients who had surgery in one eye with 164 who had cataract surgery in two eyes. ${ }^{45}$ Although both groups showed improvement those who underwent surgery in both eyes showed significantly greater improvements in all three outcomes measured: a $61 \%$ greater improvement in VF-14 score, $27 \%$ more decline in trouble with vision, and $24 \%$ improvement in satisfaction with vision during the 12 month period of follow up. This study was not a randomised controlled trial, but adjustment for patient characteristics and baseline differences in severity did not alter the results.

A recent unpublished English study of 194 patients undergoing first and then second eye surgery showed that all four dimensions of visual functioning showed significant improvement after operation on the second eye (Lawrence D, Brogan C, Benjamin L, Pickard D. The effectiveness of surgery: a study of a new patient assessed cataract outcomes instrument. Buckinghamshire Health Board, 1995). A randomised controlled trial comparing the benefits of second eye with single eye surgery is in progress in Bristol, UK. Thus efforts to save money by only treating one eye seem to be misguided. Patients with both eyes affected experience greater improvement if both cataracts are extracted and significant functional problems can remain if only one is treated..$^{50-52}$

\section{Surgical rates}

There is considerable variation in the rate of cataract surgery between English districts (fig 1) (unpublished data from the Department of Health. Hospital episode statistics data 1993-4). It is difficult to interpret such aggregate variation without more information at an individual level. It is likely to be the result of a complex interplay of supply and demand factors. ${ }^{4554} \mathrm{~A}$ study in the northern region of England showed that there was considerable variation in the level of impairment of visual acuity at which ophthalmologists decided to operate. $^{24}$

\section{Cost effectiveness of surgery}

In 1987 Drummond estimated the cost utility of cataract surgery. ${ }^{55}$ A total discounted cost of treatment and aftercare of $£ 1180$ was used and an assumption that the quality of life of people with advanced cataract was 0.6 (based on an estimate of 0.4 on a scale from 0 to 1 for people totally blind) and 0.9 after surgery (an improvement of 0.3 ) for each of the subsequent 10 years. The resulting cost

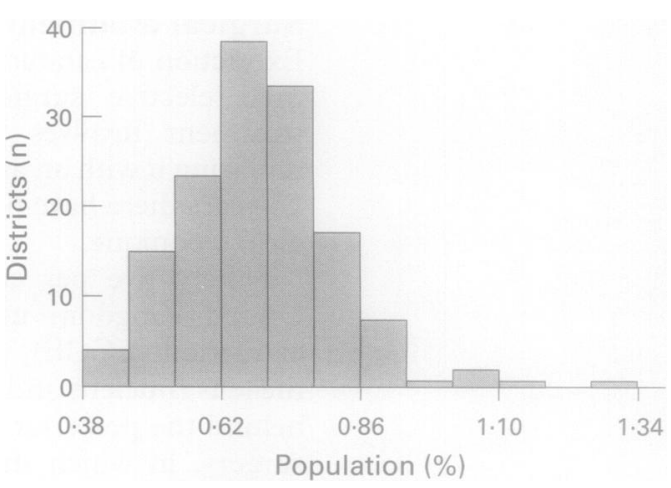

Figure 1 Distribution of rates of extraction of cataracts for adults $\geq 45$ years old by district in England 1993-4 (adjusted for age and sex).

per quality adjusted life year (QALY) was calculated to be around $£ 500$. The cost of the operation is now in the range of $£ 500-£ 1000$ depending on whether it is done on an inpatient or day case basis, ${ }^{56}$ and advances in microsurgical technique and the use of intraocular lenses have resulted in improved levels of vision after surgery. Taking into account the cost of follow up and treating complications, the current cost/QALY is likely to be $£ 1000-£ 1500$. This compares very favourably with other healthcare interventions.

Considerable caution should be used when interpreting and comparing estimates of cost utility. ${ }^{57}$ However, the conclusion that cataract surgery is cost effective in people who have, or seem to have, significant reduction in visual functioning seems to be robust.

\section{Delivery of care: day case or inpatient?}

In day case surgery, the patient is admitted, receives treatment, and is discharged in a single day. A search for comparative studies (appendix) identified four randomised controlled trials which compared day case with inpatient cataract surgery; none found any difference in outcome (table 2)..$^{5-61}$ These results are supported by case series reports. ${ }^{62-67}$

In 1985 a regulation went into effect in the United States requiring that cataract removal funded by Medicare (over 65s) should, in general, be done in outpatient settings; fees were correspondingly reduced. Now around $80 \%$ of cataract extractions in the United States are carried out as day cases. The day case rate in England has increased over the past few years from under $5 \%$ in $1989-90$ to over $20 \%$ in 1993-4 but it is below that in other European countries. $^{58}$ There is considerable variation in the day case rate across districts in England (fig 2).

A recent study in England found that only $6.5 \%$ of 480 patients were not suitable and that another $11 \%$ preferred not to have day case surgery. ${ }^{58}$ Surgical technique does not significantly influence the duration of stay, ${ }^{63}$ and both day case and inpatient cataract procedures may be performed under local or general anaesthesia. ${ }^{66}$

Most people are very satisfied with day surgery in general and cataract surgery in par- 
Table 2 Randomised controlled trials comparing inpatient with day care cataract surgery

\begin{tabular}{|c|c|c|c|c|c|}
\hline Reference and location & Subjects & Procedure & Follow up & $\begin{array}{l}\text { Outcomes } \\
\text { assessed }\end{array}$ & Results \\
\hline $\begin{array}{l}\text { Percival and Setty } \\
1992^{58} \text { Yorkshire, } \\
\text { England }\end{array}$ & $\begin{array}{l}\mathrm{n}=200: \mathrm{DC} \mathrm{n}=100, \text { IP } \\
\mathrm{n}=100 \text { Consecutive } \\
\text { patients awaiting cataract } \\
\text { surgery; relative or freind } \\
\text { available to supervise } \\
\text { convalescence and escort } \\
\text { patient to and from } \\
\text { hospital. Exclusions: } \\
\text { ocular comorbidity, local } \\
\text { anaesthesia } \\
\text { contraindicated, general } \\
\text { anaesthesia requested, ill } \\
\text { health which would } \\
\text { interfere with procedure. }\end{array}$ & $\begin{array}{l}\text { Local anaesthetic, } \\
\text { ECCE with IOL. DC } \\
\text { discharged } 6 \text { hours } \\
\text { after operation. IP } \\
\text { discharged first } \\
\text { morning after } \\
\text { operation. }\end{array}$ & $\begin{array}{l}1 \text { month; } 10-26 \\
\text { weeks after } \\
\text { operation. }\end{array}$ & $\begin{array}{l}\text { Visual acuity, } \\
\text { complications. }\end{array}$ & $\begin{array}{l}\text { No significant differences in complication rates } \\
\text { or visual outcomes. VA } \geq 6 / 9 \text { at } 1 \text { month: } 78 \% \\
\text { IP, } 75 \% \text { DC patients. VA } \geq 6 / 12 \text { at final follow } \\
\text { up: } 92 \% \text { IP, } 90 \% \text { DC patients. }\end{array}$ \\
\hline $\begin{array}{l}\text { Lowe et al } 1992^{59} \\
\text { Bristol, England }\end{array}$ & $\begin{array}{l}\mathrm{n}=442: \text { DC } \mathrm{n}=200, \mathrm{IP} \\
\mathrm{n}=242 \text { Living within } 8 \\
\text { miles of the hospital, } \geq 55 \\
\text { years. Exclusions: previous } \\
\text { intraocular procedure on } \\
\text { same eye, ocular } \\
\text { comorbidity, listed for } \\
\text { general anaesthesia, } \\
\text { significant medical or } \\
\text { psychiatric history. }\end{array}$ & $\begin{array}{l}\text { Local anaesthestic, } \\
\text { ECCE with IOL. 1st } \\
2 \text { mornings after } \\
\text { operation: DC visited } \\
\text { at home by } \\
\text { opthalmic nurse, IP } \\
\text { examined by } \\
\text { surgeon. IP } \\
\text { discharged } 2 \text { nd day } \\
\text { after operation. }\end{array}$ & $\begin{array}{l}2 \text { weeks, } 8 \\
\text { weeks, } 16 \text { weeks. }\end{array}$ & $\begin{array}{l}\text { Complications, } \\
\text { patient } \\
\text { satisfaction. }\end{array}$ & $\begin{array}{l}\text { Serious complications: } 1 \text { endopthalmitis and } 1 \\
\text { iris prolapse in each group. Postoperative patient } \\
\text { satisfaction: } 94 \% \text { happy with day case allocation, } \\
88 \% \text { happy with inpatient. No significant } \\
\text { differences between groups on any measure. }\end{array}$ \\
\hline $\begin{array}{l}\text { Galin et al } 1981^{60} \\
\text { USA }\end{array}$ & $\begin{array}{l}n=250: \text { hospital } n=82 \\
\text { hotel } n=75 \text {, home } n=93\end{array}$ & $\begin{array}{l}\text { Local anaesthestic. } \\
\text { Some had IOL. } \\
\text { Non-hospitalised } \\
\text { patients examined in } \\
\text { clinic } 7 \text { am } 1 \text { st day } \\
\text { after operation. }\end{array}$ & $\begin{array}{l}2 \text { years } \\
\text { minimum. } \\
\text { Losses not } \\
\text { described. }\end{array}$ & $\begin{array}{l}\text { Ocular results } \\
\text { (not specified), } \\
\text { complications, } \\
\text { surgical } \\
\text { reintervention. }\end{array}$ & $\begin{array}{l}\text { No significant differences in ocular results, no } \\
\text { major complications in any group. }\end{array}$ \\
\hline $\begin{array}{l}\text { Ingram et al } 1980^{61} \\
\text { Kettering, England }\end{array}$ & $\begin{array}{l}\mathrm{n}=138: 1 \text { st eye randomly } \\
\text { allocated to DC or IP, } 2 \text { nd } \\
\text { eye to alternative. } \\
\text { Exclusions }(n=7 \cdot 1): 2 \text { nd } \\
\text { eye surgery not indicated, } \\
\text { chronic disease, private } \\
\text { patient. }\end{array}$ & $\begin{array}{l}\text { Local anaesthetic. } \\
\text { DC discharged 3-6 } \\
\text { hours after operation, } \\
\text { IP dicharged } 2 \text { days } \\
\text { after operation. }\end{array}$ & $\begin{array}{l}3 \text { months and } 1 \\
\text { year, } 4 \text { patients } \\
\text { lost to follow up. }\end{array}$ & $\begin{array}{l}\text { Visual acuity. } \\
\text { Complication } \\
\text { rate. Patient } \\
\text { satisfaction. }\end{array}$ & $\begin{array}{l}\text { Visual acuity after } 1 \text { year: } 79 \% \text { of both DC and } \\
\text { IP } \geq 6 / 12 \text {. Major complications in the first year: } \\
\text { DC } 6 \text { ( } 4 \text { IOP }>25 \mathrm{~mm} \mathrm{Hg}, 1 \text { retinal } \\
\text { detachment, } 1 \text { intraocular infection); IP } 7 \text { ( } 3 \\
\text { IOP }>25 \mathrm{~mm} \mathrm{Hg}, 2 \text { retinal detachment, } 1 \\
\text { intraocular infection, } 1 \text { expulsive haemorrhage). } \\
\text { No significant differences between inpatient care } \\
\text { and day case. } 30 \% \text { of patients preferred } \\
\text { inpatient care, } 25 \% \text { preferred day case, } 45 \% \text { no } \\
\text { preference. }\end{array}$ \\
\hline
\end{tabular}

$\mathrm{DC}=$ day case ECCE = extracapsular cataract extraction; $\mathrm{IOL}=$ intraocular lens; $\mathrm{IOP}=$ intraocular pressure; IP = inpatient; VA = visual acuity.

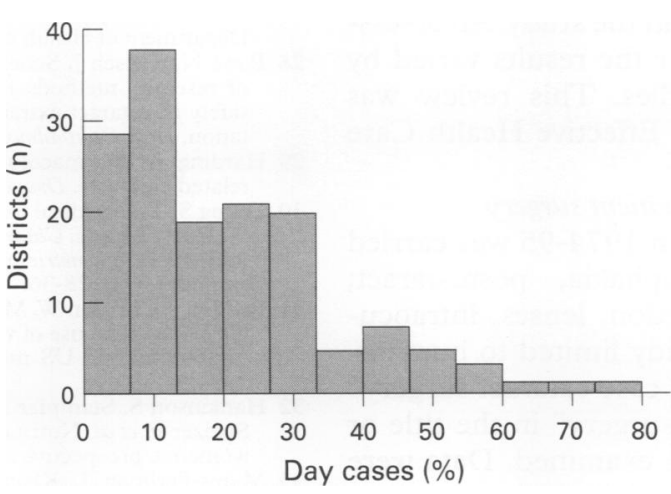

Figure 2 Day case extraction of cateracts as a percentage of the total by district in England 1993-4.

ticular, ${ }^{68}$ especially when recommended by their doctor. ${ }^{59}$ However, a survey of patients receiving day case surgery thought that they were rushed out too quickly or had problems caring for themselves after surgery. ${ }^{69}$ Often people were unsure about aftercare and thought they would have benefited from more information.

The main potential advantages of day case surgery to purchasers and providers are economic - lower hospital unit costs due to shorter hours, fewer beds, reduced postoperative care, and lower hotel costs - and the ability to treat more patients. The move towards day case surgery in the United States was associated with a $30 \%$ reduction in costs. $^{7071}$ This accords with results from a
United Kingdom randomised controlled trial which reported that the mean hospital cost per patient of day case surgery was $£ 222$ compared with $£ 366$ for inpatient treatment ${ }^{58}$ and with a study of 4000 routine operations in London which found that the cost was $30 \%$ lower in day case surgery under local anaesthetic than with inpatient care. ${ }^{72}$

The actual savings which can be made with a shift to day case surgery will depend on the degree to which fixed or semifixed costs can be reduced. ${ }^{72}$ It should also be noted that these studies only consider direct hospital costs. Savings to the National Health Service (NHS) from increasing the proportion of day case surgery involve some shift of burden in providing services to the community and to informal carers. $^{73}$

\section{Conclusions}

- Community studies in England indicate that there may be significant unmet need for treatment in older people in the United Kingdom. The effect of cataract and the decision for treatment need to be assessed in relation to the effect on the visual functioning of the patient and not exclusively on their visual acuity - Cataract surgery is a highly effective and cost effective procedure which leads to improved levels of visual acuity or functioning or both in $80 \%-90 \%$ of patients. About $20 \%$ of patients who undergo surgical treatment require laser treatment for opacification of the posterior 
capsule within two years of their surgery. The implications of this complication should be considered by those purchasing ophthalmic services

- Most patients who develop cataract do so in both eyes, although the time of appearance and rate of progression may differ. Surgery on the second affected eye results in significant benefit which may be nearly as great as that from surgery on the first eye

-Day case surgery is as effective as inpatient care, about $30 \%$ cheaper, and acceptable to patients. Around $80 \%$ of cataract operations could be done as day cases, almost four times the current United Kingdom average.

\section{Appendix}

METHODS OF REVIEWING THE LITERATURE

(1) Effectiveness of surgery and complication rates

The review of case studies and cohort studies by Powe et al ${ }^{2838}$ was based on a broad computerised search of the Medline database from 1975 to 1991 on the keywords cataract; cataract extraction; lenses, intraocular; aphakia; cataract complications; cataract, intraoperative complications; and cataract, postoperative complications. This search was supplemented by examination of bibliographies of published and unpublished reviews of cataract surgery and articles identified by consultation with experts. Data from each study were extracted blind to the journal or author and were checked by another reviewer. Each study included was assigned a quality score based on methods used in the study. An assessment was made whether the results varied by the quality of the studies. This review was updated to 1995 by the Effective Health Care Team.

\section{(2) Day case versus inpatient surgery}

A Medline search from 1974-95 was carried out on the terms aphakia, postcataract; cataract, cataract extraction, lenses, intraocular, and comparative study limited to humans. All references with "day case cataract surgery" or "outpatient cataract surgery" in the title or text of the abstract were examined. Data were extracted from all studies comparing day case and inpatient care and data from randomised controlled trials included in a table for the bulletin.

1 Leske $M$, Sperduto $R$. The epidemiology of senile cataracts: a review. Am ₹ Epidemiol 1983;118:152-65.

2 Moseley M, Hill A. Contrast sensitivity testing in clinical practice. Br $\mathcal{f}$ Ophthalmol 1994;78:795-7.

3 Masket S. Reversal of glare disability after cataract surgery. $\mathcal{f}$ Cataract Refract Surg 1989;15:165-8.

4 Bernth-Petersen P. Visual functioning in cataract patients. Methods of measuring and results. Acta Ophthalmol 1981; 59:198-205.

5 McGraw P, Winn B, Whitaker D. Reliability of the Snellen chart. $B M \mathcal{F} 1995 ; 310: 1481-2$.

6 Koch D. Glare and contrast sensitivity testing in cataract patients. $\mathcal{f}$ Cataract Refract Surg 1989;15:158-64.

7 Rubin G, Adamsons I, Stark W. Comparison of acuity, contrast sensitivity, and disability glare before and after trast sensitivity, and disability glare before and
cataract surgery. Arch Ophthalmol 1993;111:5661.

8 Wormald R, Wright L, Courtney P, Beaumont B, Haines A. Visual problems in the elderly population and implications Visual problems in the elderly population
for services. $B M Y$ 1992;304:1226-9.

9 Little B, Aylward G, Gregson R, Wormald R, Courtney P. Community ophthalmology pilot study. Eye 1993;7:180-3.
10 Harries U, Leventhal R, Poppy J. Assessing the health and social care needs of visually disabled older people. Bolton, Salford: Public Health Research and Resource Centre Trafford and Wigan Health Authorities, 1992.

11 Neumann A, McCarty G, Locke J, Cobb B. Glare disability devices for cataractous eyes: a consumer's guide. $\mathcal{F}$ Cataract devices for cataractous eyes:

12 Beckman C, Scott R, Garner L. Comparison of three methods of evaluating glare. Acta Ophthalmol 1992;70:53-9.

13 Williamson T, Strong N, Sparrow J, Aggarwal R, Harrad R. Contrast sensitivity and glare in cataract using the Pelli-Robson chart. Br $\mathcal{F}$ Ophthalmol 1992;76:719-22.

14 Morris M, Klett Z, Gieser S, Couch J, Hirsch J. Assessmen of potential contrast sensitivity. Part I: preoperative prediction of contrast sensitivity following intraocular len implantation. F Cataract Refract Surg 1991;17:37-44.

15 Klett Z, Morris M, Gieser S, Couch J, Hirsch J. Assessmen of contrast sensitivity. Part II: the relationship between objective lens opacity and laser interferometric contrast sensitivity in the cataract patient. $\mathcal{F}$ Cataract Refract Surg 1991;17:45-57.

16 Elliott $D$, Hurst $M$, Weatherill J. Comparing clinical tests of visual function in cataract with the patient's perceived visual disability. Eye 1990;4:712-7.

17 Regan D, Giaschi D, Fresco B. Measurement of glare sensiivity in cataract patients using low-contrast letter charts. Ophthalmic Physiol Optic 1993;13:115-23.

18 Regan D, Giaschi D, Fresco B. Measurement of glare susceptibility using low-contrast letter charts. Optom Vis Sci 1993;70:969-75.

19 Elliott D, Bullimore M. Assessing the reliability, discriminative ability, and validity of disability glare tests. Invest $\mathrm{Oph}-$ thalmol Vis Sci 1993;34:108-19.

20 Brogan C. Patient assessed cataract outcome pilot. (Part II MFPHM). Buckinghamshire Health Authority, 1994

21 Neumann A, McCarty G, Steedle T, Sanders D, Raanan M. The relationship between cataract type and glare disability as measured by the Miller-Nadler glare tester. 7 Cataract Refract Surg 1988;14:40-5.

22 Mangione C, Phillips R, Seddon J, Lawrence M, Cook E Dailey $\mathrm{R}$, et al. Development of the "activities of daily vision scale". A measure of visual functional status. Med Care 1992;30:1111-26.

23 Steinberg E, Tielsch J, Schein O, Javitt J, Sharkey P, Cassard $S$, et al. The VF-14. An index of functional impairment in patients with cataract. Arch Ophthalmol 1994;112:630-8.

24 Mordue A, Parkin W, Baxter C, Fawcett G, Stewar M. Thresholds for treatment in cataract surgery. $\mathcal{f}$ Public Health Med 1994;16:393-8.

25 Courtney $P$. The national cataract surgery survey: I, method and descriptive features. Eye 1992;6:487-92.

26 Desai $P$. The national cataract surgery survey: II, clinical outcomes. Eye 1993;7:489-94.

27 Agency for Health Care Policy and Research. Cataract in adults: management of functional impairment. Rockville, MD: US Department of Health and Human Services, 1993.

28 Powe N, Tielsch J, Schein O, Luthra R, Steinberg E. Rigor of research methods in studies of the effectiveness and safety of cataract extraction with intraocular lens implantation. Arch Ophthalmol 1994;112:228-38.

29 Harding J. Pharmacological treatment strategies in agerelated cataracts. Drugs Aging 1992;2:287-300.

30 Young $S$. The medical treatment of cataract. In: Douthwaite W, Hurst M, eds. Cataract: detection, measurement and man agement in optometric practice. Oxford: Butterworth Heinagement in optometric prat

31 Seddon J, Christen W, Manson J, LaMotte F, Glynn R, Buring $\mathrm{J}$, et al. The use of vitamin supplements and the risk of cataract among US male physicians. Am $\mathcal{f}$ Public Health 1994;84:788-92.

32 Hankinson S, Stampfer M, Seddon J, Colditz G, Rosner B, Speizer $F$, et al. Nutrient intake and cataract extraction in women: a prospective study. BMf 1992;305:335-9.

33 Mares-Perlman J, Klein B, Klein R, Ritter L. Relation between lens opacities and vitamin and mineral supplement use. Ophthalmology 1994;101:315-25.

34 Sperduto R, Hu T, Milton R, Zhao J, Everett D, Cheng $\mathrm{Q}$ et al. The Linxian cataract studies. Two nutrition intervention trials. Arch Ophthalmol 1993;111:1246-53.

35 Sarma U, Brunner E, Evans J, Wormald R. Nutrition and the epidemiology of cataract and age-related maculopathy. Eur f Clin Nutr 1994;48:1-8.

36 Williams M, Frankel S, Nanchahal K, Coast J, Donovan J. Cataract surgery: health care needs assessment. Bristol: Health Care Evaluation Unit, 1992.

37 The Royal College of Ophthalmologists. Guidelines for cataract surgery. London: The Royal College of Ophthalmologists, 1995.

38 Powe N, Schein O, Gieser S, Tielsch J, Luthra R, Javitt J, et al. Synthesis of the literature on visual acuity and complications following cataract extraction with intraocular lens implantation. Cataract patient outcome research team. Arch Ophthalmol 1994;112:239-52.

39 Schein O, Steinberg E, Javitt J, Cassard S, Tielsch J, Steinwachs $\mathrm{D}$, et al. Variation in cataract surgery practice and wachs $\mathrm{D}$, et al. Variation in cataract surgery practice

40 Italian-American Cataract Study Group. Incidence and progression of cortical, nuclear and posterior subcapsular progression of cortical, nuclear and posterior

41 Taylor H, Munoz B. The incidence and progression of lens opacities. Aust NZ F Ophthalmol 1991;19:353-6.

42 Magno BV, Datiles MB, Lasa S. Senile cataract progression studies using the lens opacities classification system II. Invest Ophthalmol Vis Sci 1993;34:2138-41. 
43 Mangione C, Phillips R, Lawrence $M$, Seddon J, Orav EJ, Goldman L. Improved visual function and attenuation of declines in health-related quality of life after cataract extraction. Arch Ophthalmol 1994;112:1419-25.

44 Brenner M, Curbow B, Javitt J, Legro M, Sommer A. Vision change and quality of life in the elderly. Response to cataract surgery and treatment of other chronic ocular conditions. Arch Ophthalmol 1993;111:680-5.

45 Javitt J, Steinberg E, Sharkey P, Schein O, Tielsch J, Diener West $\mathrm{M}$, et al. Cataract surgery in one eye or both: a billion dollar per year issue Ophthalmology 1995;102:1583-93.

46 Lee P, Kamberg C, Hilborne L, Massanari RM, Kahan J, Park $\mathrm{R}$, et al. Cataract surgery: a literature review and rating of appro

47 Masket S. Complications of cataract and intraocular len surgery. Curr Opin Ophthalmol 1992;3:52-9.

48 Javitt J, Tielsch J, Canner J, Kolb M, Sommer A, Steinberg E. National outcomes of cataract extraction. Increased ris of retinal complications associated with Nd:YAG laser capsulotomy. Ophthalmology 1992;99:1487-97.

49 Leibowtiz HM, Krueger D, Maunder L, Milton R, Kini M, Kahn $\mathrm{H}$, et al. The Framingham eye study monograph. Surv Ophthalmol 1980;(suppl):333-63.

50 Hillbourne JFH. Social and other aspects of adjustment to single eye cataract extraction in elderly patients. Transac tions of the Ophthalmological Societies of the UK 1975; tions of the

51 Laidlaw A, Harrad R. Can second eye cataract extraction be justified? Eye 1993;7:680-6.

52 Javitt J, Brenner M, Curbow B, Legro M, Street D Outcomes of cataract surgery. Improvement in visual acuity and subjective visual function after surgery in the first, second, and both eyes. Arch Ophthalmol 1993;111:686-91.

53 Escarce J. Would eliminating differences in physician practice style reduce geographic variations in cataract surgery rates? Med Care 1993;31:1106-18.

54 Sanderson $\mathrm{H}$. Regional variation in cataract extraction rates and their relationship with resource supply and need. $\mathcal{F} R$ Soc Med 1980;73:492-6.

55 Drummond M. Economic aspects of cataract. Ophthalmol ogy 1988;95:1147-53.

56 Jefferys E. Shifting to day case surgery: an investigation of cataract extractions in North Yorkshire. York: North Yorkshire Health Authority, 1995 .

57 Mason J, Drummond M, Torrance G. Some guidelines on the use of costeffectiveness league tables. BMF 1993 306:570-2.
58 Percival S, Setty S. Prospective audit comparing ambulatory day surgery with inpatient surgery for treating cataracts. Quality in Health Care 1992;1:38-42.

59 Lowe K, Gregory D, Jeffery R, Easty D. Suitability for day case cataract surgery. Eye 1992;6:506-9.

60 Galin M, Boniuk V, Obstbaum S, Barasch K, Baras I. Hospitalization and cataract surgery. Ann Opthalmol 1981; 13:365-7.

61 Ingram RM, Banerjee D, Traynar M, Thompson R. Day-case cataract surgery. Trans $R$ Opthalmol UK 1980; 100:205-9.

62 Vernon S, Cheng H. Comparison between the complications of cataract surgery following local anaesthesia with short stay and general anaesthesia with a five-day hospitalisation. Br $\mathcal{F}$ Ophthalmol 1985;69:360-3.

63 Schanzer M, Wilhelmus $\mathrm{K}$. Outpatient cataract surgery by ophthalmology residents in a county hospital. Ann Opthalmol 1985;17:480-2.

64 Elsas T, Guldahl J, Blika S, Hoisen H, Brevik T, Ringvold A. Outpatient anterior chamber lens implantation. Acta Ophthalmol 1988;66:214-6.

65 Holland G, Earl D, Wheeler N, Straatsma B, Pettit T, Hepler $\mathrm{R}$, et al. Results of inpatient and outpatient cataract surgery. A historical cohort comparison. Ophthalmology 1992;99:845-52.

66 Strong N, Wigmore W, Smithson S, Rhodes S, Woodruff G Rosenthal A. Daycase cataract surgery. $\mathrm{Br} \mathcal{F}$ Ophthalmol 1991;75:731-3.

67 Javitt J, Street D, Tielsch J, Wang Q, Kolb M, Schien O, et al. National outcomes of cataract extraction. Retinal detach ment and endophthalmitis after outpatient cataract surgery. Ophthalmology 1994;101:100-5.

68 Davies B, Tyers A. Do patients like day case cataract surgery? Br $\mathcal{F}$ Ophthalmol 1992;76:262-3.

69 North Tyneside Community Health Council. In for a day. North Tyneside: North Tynside General Hospital, 1995.

70 Bloom B, Krueger N. Cost and quality effects of outpatient cataract removal. Inquiry 1988;25:383-7.

71 Steinberg E, Javitt J, Sharkey P, Zuckerman A, Legro M, Anderson $\mathrm{G}$, et al. The content and cost of cataract surgery. Arch Ophthalmol 1993;111:1041-9.

72 Aylward G, Larkin D, Cooling R. Audit of cost and clinical outcomes of cataract surgery. Health Trends 1993;25:1269.

73 Ancona-Berk V, Chalmers T. An analysis of the costs of ambulatory and inpatient care. Am $\mathcal{F}$ Public Health 1986;76:1102-4 